\title{
AUDIT OF OCCUPATIONAL HEALTH AND SAFETY IN AN ENTERPRISE OF THE CERAMIC SECTOR IN THE STATE OF AMAZONAS/BRAZIL
}

\author{
AUDITORIA DE SAÚDE E SEGURANÇA OCUPACIONAL EM UMA EMPRESA DO SETOR CERÂMICO NO ESTADO DO \\ AMAZONAS/BRASIL
}

\section{(D) Thaís Mendes Repolho ${ }^{1}$ \\ Moisés Andrade Coelho²}

${ }^{1}$ Bacharel em engenharia de produção Instituto de Ciências Exatas e Tecnologia

(ICET/UFAM)

thmendesrepolho@gmail.com

${ }^{2}$ Mestre em engenharia de produção Instituto de Ciências Exatas e Tecnologia (ICET/UFAM) moisescoelho@ufam.edu.br

\begin{abstract}
This work aims to conduct an audit of occupational health and safety in an enterprise of the ceramic sector in the state of Amazonas. Regarding the approach to the problem, this study is characterized as quantitative and exploratory regarding the objectives. The research technique used was the case study in a ceramic sector company located in the state of Amazonas. Among the main results are the more in-depth analysis of the activities carried out within the enterprise, identifying the risk factors in the different sectors, identifying the most positive and negative standards, and thus being able to ascertain if they are in agreement with the which is established. The relevance of the study lies in the application of an instrument that makes it possible to identify the main risk factors related to occupational safety and health.
\end{abstract}

Keywords: Ergonomics. Audit of Occupational Health and Safety. Regulatory Norms. Ceramic Sector. Amazonas.

\section{Resumo}

Este trabalho objetiva conduzir uma auditoria de saúde e segurança ocupacional em uma empresa do setor cerâmico no estado do Amazonas. Com relação à abordagem do problema, este estudo caracteriza-se como quantitativo e exploratório no que tange os objetivos. A técnica de pesquisa utilizada foi o estudo de caso em uma empresa do setor cerâmico localizada no estado do Amazonas. Entre os principais resultados estão análise mais aprofundada das atividades desenvolvidas na empresa, identificando os fatores de riscos nos diferentes setores, identificando padrões mais positivos e negativos, podendo assim verificar se estão de acordo com o que está estabelecido. A relevância do estudo reside na aplicação de um instrumento que possibilita identificar os principais fatores de risco relacionados à saúde e segurança ocupacional.

Palavras-chave: Ergonomia. Auditoria de Saúde e Segurança Ocupacional. Normas Regulamentadoras. Setor cerâmico. Amazonas. 


\section{Introduction}

Ergonomics is the discipline related to understanding the interactions between humans and other elements of a system, and the profession applies theories, principles, data, and methods to design for the purpose of optimizing human well-being and system performance as a whole (IEA, 2019).

Its emergence was due to concerns about improving the efficiency of human work and reducing man's suffering at work, thus preventing risks to his health. Its origins have come from antiquity, where physicians and sanitarians have sought to describe the consequences of work for health, understanding its mechanisms and identifying its causes for finding ways to prevent it. Experts from various fields, such as engineering, medicine, and psychology, sought to define the amount of work that could be required of a man without fatigue or excessive wear (Falzon, 2007).

It is a science applied to the design of machines, equipment, systems, and tasks, to improve safety, health, comfort and efficiency at work. It is based on knowledge of other scientific areas, involving anthropometry, biomechanics, physiology, psychology, toxicology, among others, gathering and integrating the relevant knowledge of these areas and developing specific methods and techniques to apply this knowledge to improve work and conditions, both for workers and for the general population (Dul \& Weerdmeester, 2004).

Occupational health and safety encompasses the social, mental and physical well-being of workers through health and safety measures that require the collaboration and participation of both employers and workers in health and safety programs, forcing them to address issues. related to occupational medicine, occupational hygiene, toxicology, safety engineering, ergonomics, among others. That is, poor working conditions affect worker health and safety (International Labor Office, 2009).

Occupational health and safety programs, as a result of the prevailing culture in the vast majority of companies, are usually designed and oriented to comply with the legislation on the subject. Thousands of people die or mutilate each year in Brazil as a result of work-related accidents, the causes of which range from precarious physical conditions in the environment to various forms of organizational distortion and inappropriate worker behavior (Oliveira, 2003).

The traditional approach to risk is based on the identification of elements that may cause health damage in certain circumstances; These dangerous elements are called risk factors. These approaches improve working conditions, but are only possible for objectifiable risk factors that are object of relatively stabilized knowledge (Ruiz \& Araújo, 2012).

In the analysis of occupational health and safety, it is necessary to consider the political guidelines and their actions, the institutional responsibilities and the effective fulfillment of responsibilities by the organizations related to the area. The organization and effective implementation of a National Occupational Safety and Health Policy (PNSST) in Brazil has been 
attempted for some years by understanding and enabling the assignment of each of the ministries directly related to the theme (Servo, Salim \& Chagas, 2011).

As for repetitive strain injuries (RSI) or also known as work-related musculoskeletal disorders (DORS), they deal with diseases of the musculoskeletal system involving the neck and upper limbs, whether or not they are related to work. These functional disorders occur more frequently due to neuromuscular fatigue, which is caused by many hours of work in a single position or by the repetition of the same movement of the upper limbs (Rocha, 2004).

In this way, this work aims to conduct an audit of occupational health and safety in an enterprise of the ceramic sector in the state of Amazonas. The study is structured in three parts: (1) review of the literature on ergonomics and regulatory standards; (2) methodology; and (3) results, discussion, conclusion, and references. The relevance of the study lies in the application of an instrument that makes it possible to identify the main risk factors related to occupational safety and health.

\section{Literature review}

\subsection{Ergonomics}

Ergonomics has two objectives, one that is focused on organizations and their performance, which includes efficiency, productivity, reliability, quality, durability, and another that is peoplecentered and unfolds in different dimensions, such as safety, health, comfort, ease of use, satisfaction, work interest, pleasure, among others (Falzon, 2007).

The areas of specialization of ergonomics are three: (1) physical ergonomics, related to anatomical, anthropometric, physiological and biomechanical characteristics related to physical activity; (2) cognitive ergonomics, related to mental processes, such as perception, memory, reasoning and motor response, as they affect the interactions between humans and the other elements of a system; and (3) organizational ergonomics, deals with the optimization of sociotechnical systems, including their organizational structures, policies and processes (IEA, 2019).

It covers various administrative sectors working in communion to improve working conditions. The contribution of ergonomics is classified as (1) conception, (2) correction, (3) awareness and (4) participation. The ergonomics of design makes an analysis of the situations that can happen, that is, it occurs during the design of the product, the machine, environment or system. When a correction is applied to solve the problem that is interfering with safety, causing excessive fatigue, illness in the worker or quantity and quality of production, it is referred to as ergonomics of correction. The ergonomics of awareness seeks to enable workers to detect and correct the problems that occur from day to day. Participation ergonomics seeks the help of workers to find the solution to the problem detected (lida, 2005). 
Ergonomics seeks to correct the imbalances caused by the disproportion between the care given to the manufacture of machines and those who operate the services. There is a diversity of forms of the intervention of the ergonomic action, either through the implementation of actions as a diagnosis to understand the difficulties encountered or the health problems, enrollment in processes of change or conduction of projects. It can be applied in production or service by both ergonomists and by untrained people in the area, such as a designer, who could use ergonomics through general standards or recommendations. Therefore, the ergonomic action is based on the capacity to gather knowledge and methods adapted to each situation (Daniellou \& Béguin, 2007).

The main purpose of ergonomic action is the transformation of work so that it can contribute to the conception of work situations that do not interfere in the health of the operators, where they can carry out their competences, individually or collectively, valuing their abilities, besides achieving the economic objectives determined by the company. Ergonomics has as its object the study of work, and can designate the working conditions (hard work, heavy work), the result of the work (if the work was poorly done, or if it is the first job) or the activity itself (how to do the work meticulously and without overcharging) (Guérin et al., 2001).

Ergonomics seeks to influence the design and reconception of the working environment through recommendations made after an environmental analysis. The design of the means of work implies in complex processes that the ergonomist must learn to know and participate in order to influence them and obtain significant results. In ergonomics of design, work is the object of ergonomic intervention, where the ergonomist needs to develop methods of approach for the activity to be analyzed. This approach should implement operative modes that are compatible with the chosen criteria, in terms of health, productive efficiency, personal development and collective work (Daniellou, 2007).

One of the characteristics of conception is paradoxical temporality, which is the production of something that is not yet known, since in the beginning one does not have the prediction of the future situation, and in the end, there is already much more information. On the other hand, there are initially many possibilities and a number of choices are possible, but as choices are made, the actors' degrees of freedom diminishes. The conception is a group work, whatever the work or product to be conceived will require more than one person to solve it, in this way, tasks are differentiated, distributed and attributed to the actors according to the technical specialty of each one (Béguin, 2007).

\subsection{Regulatory norms}

The development of safety at work occurred in conjunction with the search for social welfare, where this security is not only seen as a science or a requirement of public agencies, but rather as a path traveled by humanity seeking social welfare, promoting improvement in workers' health and 
safety. With this, it can be said that safety at work is concerned with identifying risks, analyzing them and evaluating them for each activity, thus seeking, eliminating and controlling them (Chibinski, 2011).

In 1943, the Consolidation of Labor Laws was instituted, but only from 1977, by law 6,514, which approved ordinance 3,214 of 1978, that the Regulatory Norms (NRs) were approved. The norms cover legislation and health at work and as their absence in the prevention of occupational risks can lead to occupational diseases, accidents at work, unemployment, disability, and reduced functional capacity. The Federal Constitution of 1988 guarantees punishment to companies in which workers do not act in appropriate ergonomic conditions (Rocha, 2004).

The main research-related NRs will then be presented in order to have an understanding of each of them.

NR-4 (Specialized Services in Safety Engineering and Occupational Medicine) aims to promote and protect the health and integrity of the worker in the workplace. This NR must be applied in companies that have more than $50 \%$ of their employees in establishments or sectors whose activity is higher than the main activity (Brasil, 1983).

The NR-5 CIPA (Internal Commission for the Prevention of Accidents) aims to prevent accidents and diseases arising from work. The CIPA is mandatory for companies that have employees with a job link. It must be constituted taking into consideration the number of employees effectively linked to the bargaining regime (Brasil, 1999).

NR-6 (Personal Protective Equipment) aims to avoid susceptible hazards that may threaten safety and health at work. This NR says that the company is obliged to provide its employees with a EPI (personal protective equipment) that is free of risk, in a perfect state of repair and operation, provided that the general measures do not offer complete protection against the risks of accidents. Work, while collective protection measures are being implemented and to respond to emergency situations (Brasil, 2001).

The Occupational Health Medical Control Program (NR-7) aims to promote and preserve the health of all its workers. It is recommended that this NR be applied in all contracting companies of service providers and should inform the existing risks, assisting in the elaboration and implementation of the PCMSO (Medical Control Program and Occupational Health) in the workplaces where the services are being rendered (Brasil, 1994).

The NR-8, which deals with Buildings, aims to establish minimum technical requirements that must be observed in buildings, with the purpose of guaranteeing safety and comfort to those who work there (Brasil, 1983).

NR-9, which deals with the Environmental Risk Protection Program (PPRA), aims at preserving the health and integrity of workers through the anticipation, recognition, evaluation and consequent control of the occurrence of existing or emerging environmental risks to existing in the workplace, taking into account the protection of the environment and natural resources. The actions of this NR 
should be developed depending on the characteristics of the risks and the control needs of the companies. The application within the company must take into account a series of risks, which are environmental, physical, chemical and biological, that exist in the workplace and that, due to their nature, concentration or intensity and time of exposure, are capable of cause damage to the worker's health (Brasil, 1994).

Safety at work in machinery and equipment (NR-12), aims to guarantee the health and physical integrity of workers, establishing minimum requirements for the prevention of accidents and occupational diseases in the design and use of machinery and equipment of all kinds. This NR serves for the employer to adopt protective measures for work on machines and equipment, ensuring the health, physical integrity of workers, and appropriate measures whenever people with disabilities are directly or indirectly involved in work (Brasil, 2010).

NR-14 for furnaces states that ovens must be solidly constructed, lined with refractory material, so that the heat does not exceed the tolerance limits established by NR-15 (unhealthy) (Brasil, 1983).

The aim of NR-17 regarding ergonomics is to establish parameters that allow the adaptation of working conditions to the psychophysiological characteristics of the workers, in order to provide maximum comfort, safety, and efficient performance. This NR must be applied in companies whose working conditions include aspects related to lifting, transportation, and unloading of materials, furniture, equipment and environmental conditions of the workplace and to the organization of work. In order to evaluate the adaptation of working conditions, it is the responsibility of the employer to perform the ergonomic analysis of the work, and at least the working conditions must be addressed, as established in this regulatory standard (Brasil, 1990).

NR-23 (Fires) aims to prevent fires. This NR must be applied by all employers for fire prevention, in accordance with state legislation and applicable technical standards. The employer must provide all workers with information on the use of fire-fighting equipment, safe evacuation procedures and existing alarm devices (Brasil, 2011).

The NR-15 that treats the unhealthy, aims to avoid unhealthy activities or operations above the limits of tolerance, not to cause damage to the health of the worker during his working life. This NR mentions that companies should request the Ministry of Labor, through the DRTs (Regional Labor Stations) to carry out expertise in their establishment or sector, in order to characterize and classify or determine unhealthy activity (Brasil, 1978).

\section{Methodology}

Combined research approach allows for a better understanding of the research problems that each approach (quantitative and qualitative) would allow separately. The combination enables the advantages and disadvantages of each approach to be mitigated. Thus, we work with broader research 
questions that would not be addressed using one of them alone (Miguel, 2012). This study used a quantitative survey through the form of auditing and a qualitative survey by the application of direct observation of the productive environment and semi-open interviews.

As for the objectives, the approach used was exploratory. The exploratory research aims to provide greater familiarity with the problem in order to make it explicit or to construct hypotheses (Silva \& Menezes, 2005). The study sought to make explicit ergonomic and safety related issues and work health in the ceramic enterprise.

The technical procedure used was the case study, which seeks to examine the contemporary events where the behaviors of the research subjects cannot be manipulated, with the theoretical prepositions being generalizable (Yin, 1994). The case study was applied to a ceramic enterprise in the state of Amazonas/Brazil.

The case study is a methodological procedure in which it examines a phenomenon in its natural setting, employing multiple methods of collecting data to collect information from one or a few entities, such as individuals, groups or organizations (Benbasat et al., 1987).

This procedure allows simple handling of complex situations considering that a phenomenon is influenced by the context in which it is inserted. However, embracing a field research technique, such as case studies, forces the researcher to become individual, and the field in general prepares for the resolution of real problems of operations management in a richer and better way (Baxter \& Jack, 2008; McCutcheon \& Meredith, 1993).

In the case of operations management and related areas, evidence demonstrates the contribution of the cases in terms of the construction of theories in new areas and the integration between the theory applied in new contexts and the scientific rigor appropriate to the area (Barrat et al. 2011; Voss et al., 2002).

For this research, the model presented by Castro and Okawa (2016) was used, which sought to identify the risk factors in the different work sectors in relation to the equipment; substances and materials; ergonomic factors; and organizational factors.

The audit of occupational health and safety considered occupational, physical, chemical, biological, ergonomic and accident hazards.

The form consists of 55 affirmative questions and organized into 11 items related to the regulatory standards of Specialized Services in Safety Engineering and Occupational Medicine - SESMT (NR-4); Internal Commission for the Prevention of Accidents - CIPA (NR-5); Medical Occupational Health Control Program - PCMSO (NR-7); Buildings (NR-8); Program of Prevention of Environmental Risks - PPRA (NR-9); Safety in Work in Machinery and Equipment (NR-12); Ovens (NR-14); Ergonomics (NR-17); Fires (NR-23); Personal Protective Equipment - EPI (NR-6); and Unhealthy (NR-15).

Each observed situation was classified on a scale from 0 to 3 as follows: (0) does not apply; (1) does not answer; (2) partially implanted, in implantation or partially executed; and (3) yes, answer. 
The sampling used in the research was intentional non-probabilistic. Marconi and Lakatos (1990), affirm that in the intentional non-probabilistic sampling the opinion of certain elements of the population, that is, of a representative of a certain social body.

The research techniques used, according to Marconi and Lakatos (1990), were: (1) indirect documentation, through documents made available by the enterprise; (2) bibliographic research; (3) direct documentation, carried out through field research in the ceramics industry; (4) Intensive direct observation, implemented through semi-open interviews; and (5) Extensive direct observation through the audit of occupational health and safety form.

The study was carried out in three moments: (1) individual semi-open interviews (carried out with owner, manager of the productive area and work safety technician) and collective interviews with workers of the productive process (Vergara, 2009) based on Guérin et al. (2001), where key information was identified for completing the form applied in the enterprise later; (2) documentary research was carried out in order to collect preliminary data on documents made available by the enterprise (standard operations, flowchart, production plans, quality indicators, among others);

Then, (3) the structured observation (Vergara, 2009) of the execution of the activities by the employees of the productive sector happened. In the structured observation, a better understanding of the enterprise was sought through the analysis of the physical infrastructure of the production, the gestures, postures, actions and communications between the employees of the sectors and between them; (4) application the audit of occupational health and safety form in the Organization \& Methods and Quality departments (after interviews and structured observation).

The quantitative data of the audit form were analyzed in a way that would allow an adequate understanding of how these practices occur within the enterprise and enable the visualization through the spider chart.

The qualitative data obtained from the responses of the roadmap were tabulated in a summary table, grouped according to the content and stratified according to the structure of form. The documentary information collected at the second moment was integrated and triangulated with the information collected by the interviews in order to ensure rationalization and validation.

For the qualitative data analysis we used the methodology proposed by Kvale (1996) starting with the description of the subject from the experience of the owner, manager of the productive area and occupational safety technician during individual interviews and with workers in collective interviews. Then, we sought to discover new relationships of the theme and how respondents observe and put it into practice.

During the interviews, we sought to condense and interpret the meaning of what the interviewees described, disseminate and return in feedback until there is only one possible interpretation or multiple understandings of the subject by the subjects. The transcribed interviews were interpreted. The material was structured and clarification followed in order to eliminate 
repetitions and distinctions between the essential and the nonessential. The analysis involved the development of the meanings of the interviews, bringing the proper understanding of the theme, as well as providing new perspectives of the researcher on the phenomenon analyzed.

In conclusion, the interview had a character of action by enabling those involved, from the questions, the beginning of new insights on safety and health activities in the workplace that could be adopted by the enterprise.

\section{Results}

\subsection{Enterprise characterization}

The research of this study in a medium enterprise of the ceramic sector located in the municipality of Itacoatiara (Amazonas State/Brazil). Among the ceramic products manufactured by the enterprise are: eight-hole bricks, six holes, four holes, blocks, tiles and tiles, the eight-hole brick being the biggest selling product, followed by the six- and four-hole bricks. Figure 1 shows the production process for the manufacture of bricks.

Figure 1 - Flow chart of the Alpha Enterprise Productive Process

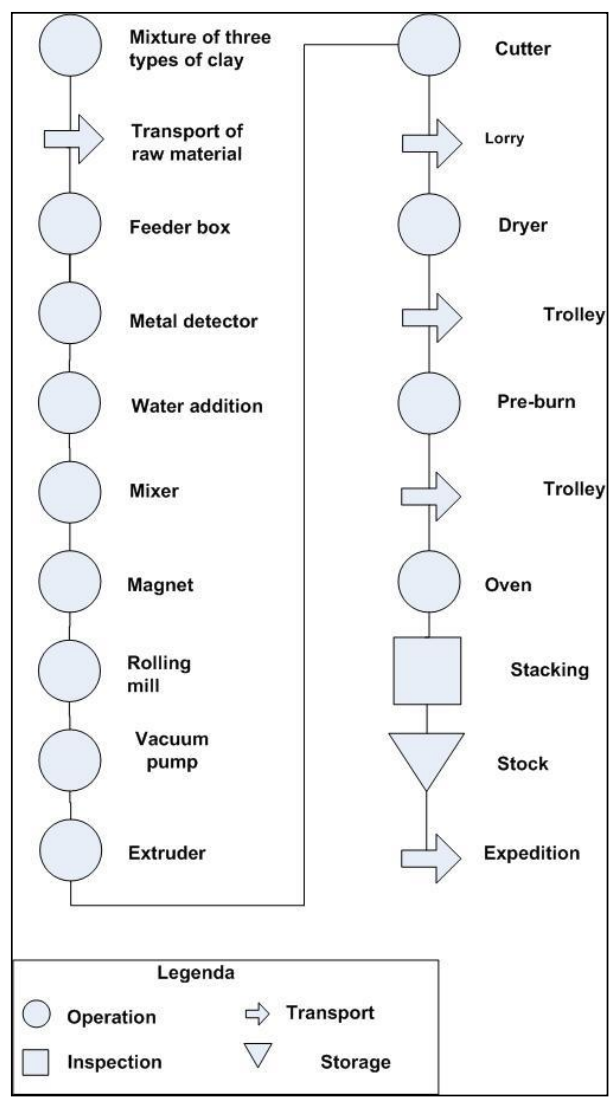

Source: Own. 
Due to its location in the Amazon region, the enterprise uses biomass to feed the kiln from legalized and reforested wood, in addition to extracting the raw material (clay) from the area authorized for exploitation.

Currently, the enterprise has 45 employees, one trainee, and two major partners, and has a daily production of 80,000 (eighty thousand) pieces, having a monthly goal of 1,800,000 (one million, eight hundred thousand) pieces. Figure 2 shows the floor plan of Alpha Enterprise.

Figure 2 - Alpha Enterprise floor plan

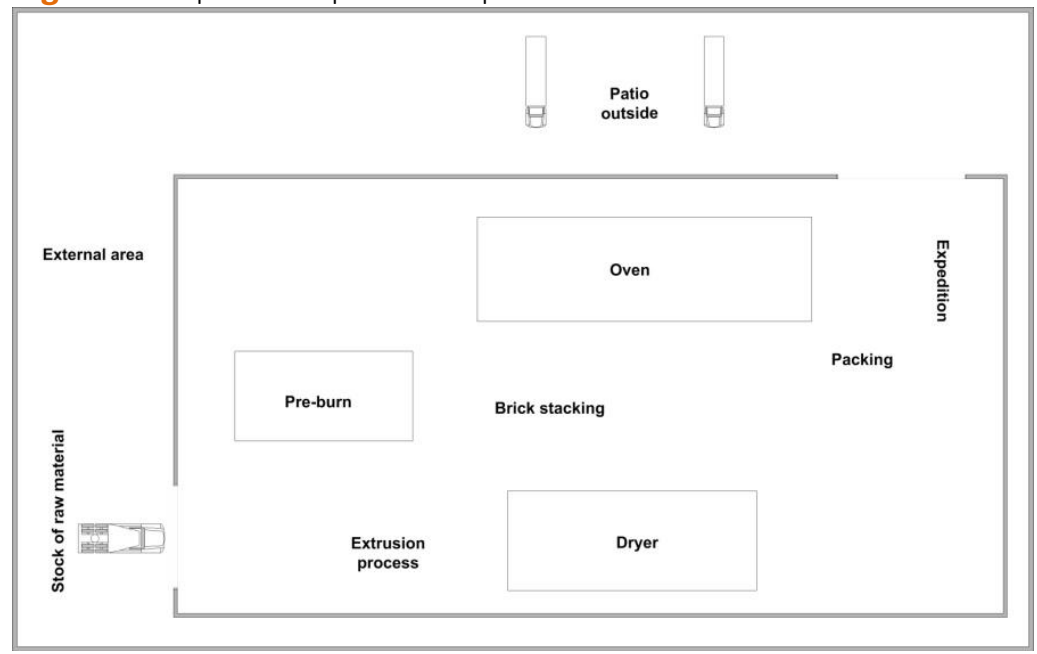

Source: Own

\subsection{Application of the audit of occupational health and safety}

The application of the audit of occupational health and safety in the enterprise was first made through a form where the interview with the occupational health and safety technician of the ceramics industry studied was carried out. The regulatory standards highlighted for the study were: NR-4 (Specialized Service in Safety Engineering and Occupational Medicine - SESMT); NR-5 (Internal Commission for the Prevention of Accidents - CIPA); NR-6 (Personal Protective Equipment - EPI); NR-7 (Medical Occupational Health Control Program - PCMSO); NR-8 (Buildings); NR-9 (Program of Prevention of Environmental Risks - PPRA); NR-12 (Safety in Work in Machinery and Equipment); NR14 (Ovens); NR-15 (Unhealthy); NR-17 (Ergonomics); and NR-23 (Fires).

Eleven (11) regulatory standards were considered and addressed in the total, which was asked specific questions following what is pre-established in the ordinance of each one, that is, if the standards are being applied in the enterprise and if they comply with the regulations.

Based on the research done and the answers obtained through the form, an analysis was made of the NRs that are or are not implanted in the enterprise and the necessary care is taken to maintain the physical integrity of the workers. 


\subsubsection{Specialized Service in Safety Engineering and Occupational Medicine - SESMT}

NR-4 (Specialized Services in Safety Engineering and Occupational Medicine - SESMT) is not implanted in the enterprise since it has a number of employees below the minimum that is established by the standard since the SESMT sizing is made from the 50 employees and the enterprise has only 45 employees in total.

\subsubsection{Internal Commission for the Prevention of Accidents - CIPA}

It was observed that the NR-5 (Internal Commission for the Prevention of Accidents - CIPA) is established in the enterprise, fulfilling what is established in relation to its attributions, operation, training, and the electoral process. In this way, the enterprise seeks to make the sectoral identification of the existing risks, using a risk map. In addition, an annual calendar of monthly meetings is stipulated, which are made on the last Wednesday of each month. The training is carried out during the working hours of the employee and can be divided into 05 (five) days, depending on the operational availability, since the minimum workload is 20 (twenty) hours. Already the electoral process is formed and published 60 (sixty) days before the end of the previous administration.

\subsubsection{Personal Protective Equipment - EPI}

It was verified that all the workers of the enterprise have the personal protective equipment and it was observed that the regulatory norm is being partially executed by the enterprise since it makes available the EPI and requires its mandatory use, as shown in Figure 3, but not in perfect condition. In addition, it was observed that despite the enterprise providing the training and proper use of the equipment, only some employees do and there is no supervision regarding its use in the day to day operating.

Figure 3 - Signage for the use of EPI in Alpha Enterprise

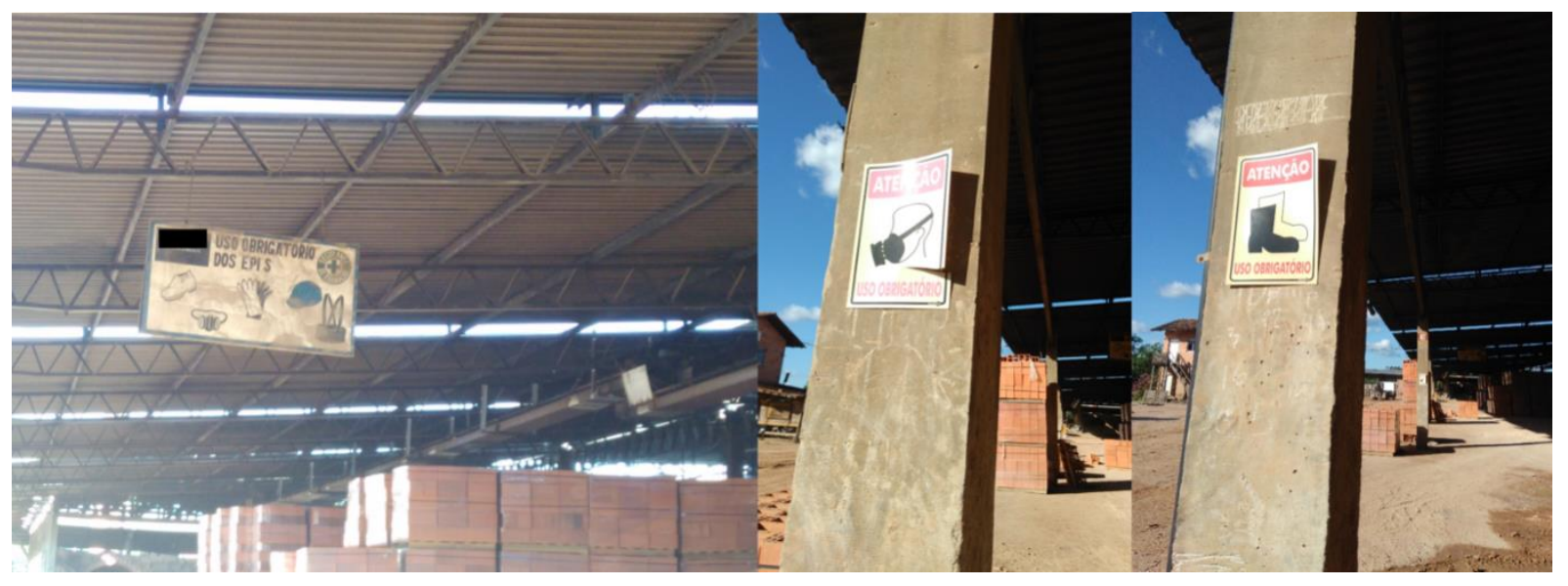

Source: Own. 


\subsubsection{Medical Occupational Health Control Program - PCMSO}

The enterprise is in agreement with what is established in the ordinance of NR-7 regarding the object, guidelines, responsibilities, and development, working in order to have a work doctor and to make periodic examinations to its employees.

\subsubsection{Buildings}

The enterprise has the NR-8 partially implanted since despite having fixed ramps and stairs in good condition, the place has problems of floors and slippery ramps. In addition, ladders with small diameters and uneven flooring problems have also been observed, which may compromise worker safety.

\subsubsection{Program of Prevention of Environmental Risks - PPRA}

It was verified that NR-9 is deployed in the enterprise, functioning in order to evaluate the operational area, according to the risks in the work environment, complying with the established standards, where only three (3) environmental risk assessments: physical (noise, dust, temperature, humidity); chemicals (fog, gases, vapors); (fungi, bacteria, parasites, protozoa). Once workers are exposed daily to these agents, the enterprise seeks to make assessments and from them, the specific EPIs are sized for each operational risk they are exposed to.

\subsubsection{Safety in Work in Machinery and Equipment}

It was observed that NR-12 is not implanted in the enterprise, where the demarcations around the machines and equipment were not found, as evidenced in Figure 4.

Figure 4: Safety of work on machines and equipment at Alpha Enterprise

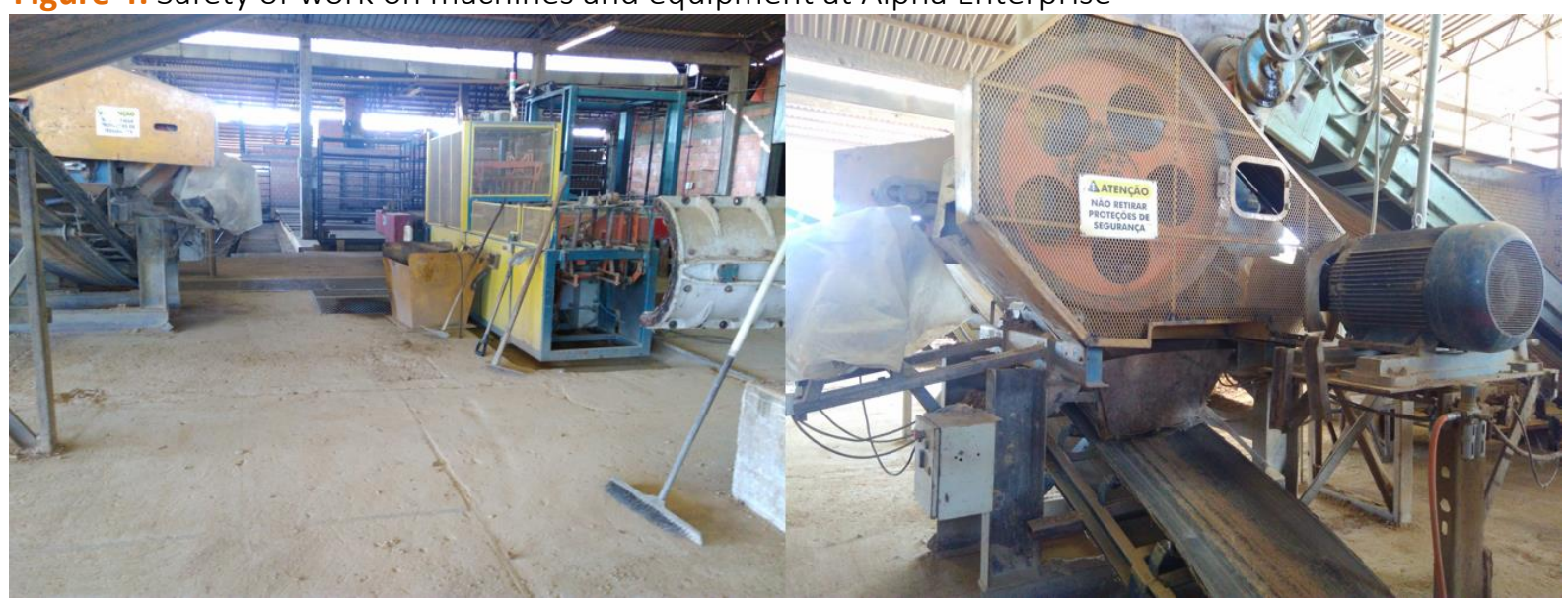

Source: Own. 
As a ceramic industry, which has three types of clay for the manufacture of its product, it was observed that the material to be used lies in an area where there is no demarcation in the color indicated by the standard (Figure 5). In addition, there are facilities and electrical devices that are not in good repair.

Figure 5 - Types of clay used in Alpha Enterprise

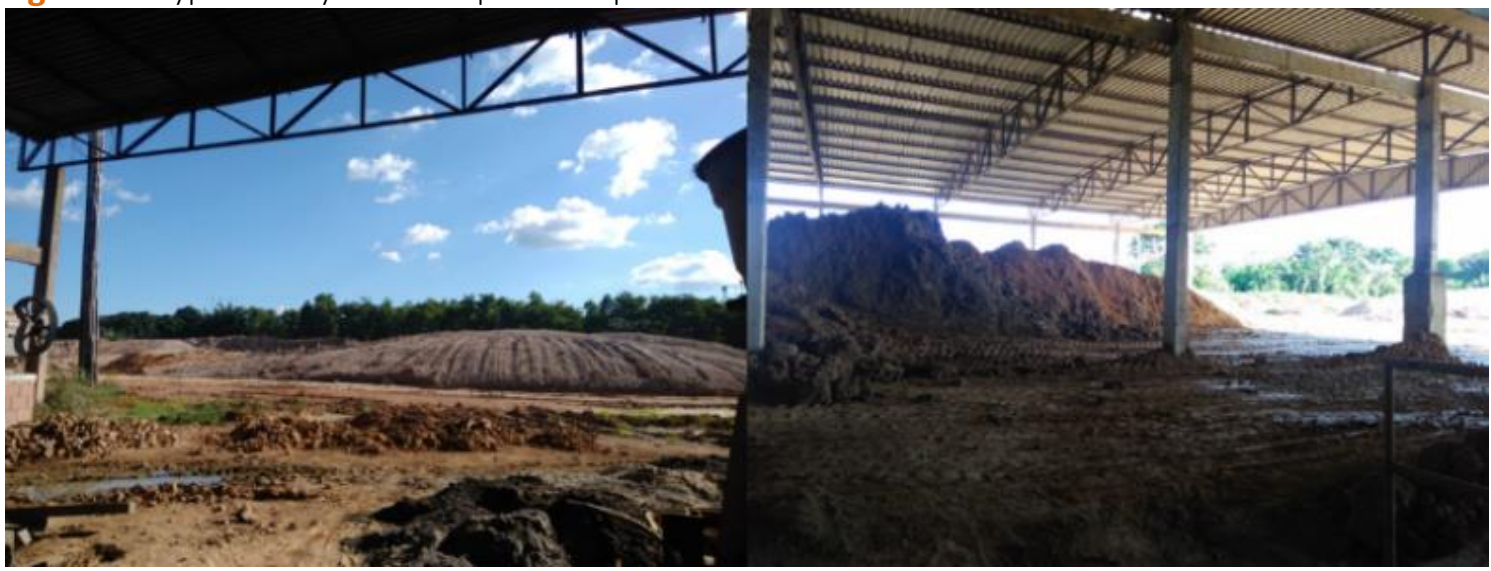

Source: Own.

\subsubsection{Ovens}

The standard is implanted in the enterprise, so the ovens are coated with refractory material, so that the heat does not exceed the limits of tolerance, according to the parameter of NR-14, without harming the comfort of the worker and allowing the free exhaust gases.

\subsubsection{Unhealthy}

The enterprise seeks to control the agents through EPI and EPC, and annual evaluations are carried out to measure the agents (chemical, physical and biological) mentioned in NR-9. It has been observed that in the extrusion area there is little noise, however, the employees of this production area make use of the ear muffs for protection against such agents.

\subsubsection{Ergonomics}

The NR-17 is partially implanted in the enterprise. It was observed that some working conditions are not adapted to the workers, being able to mention the activities that are carried outstanding and the lack of seats for the rest of the workers, in this way, the work is carried out during the whole working day. Although there is a manual loading of cargo (Figure 6), it occurs intermittently, that is, the weight of the product does not exceed that recommended by the standard. In addition, there are mechanical means for the displacement of the pallets in the productive environment by means of forklifts. 


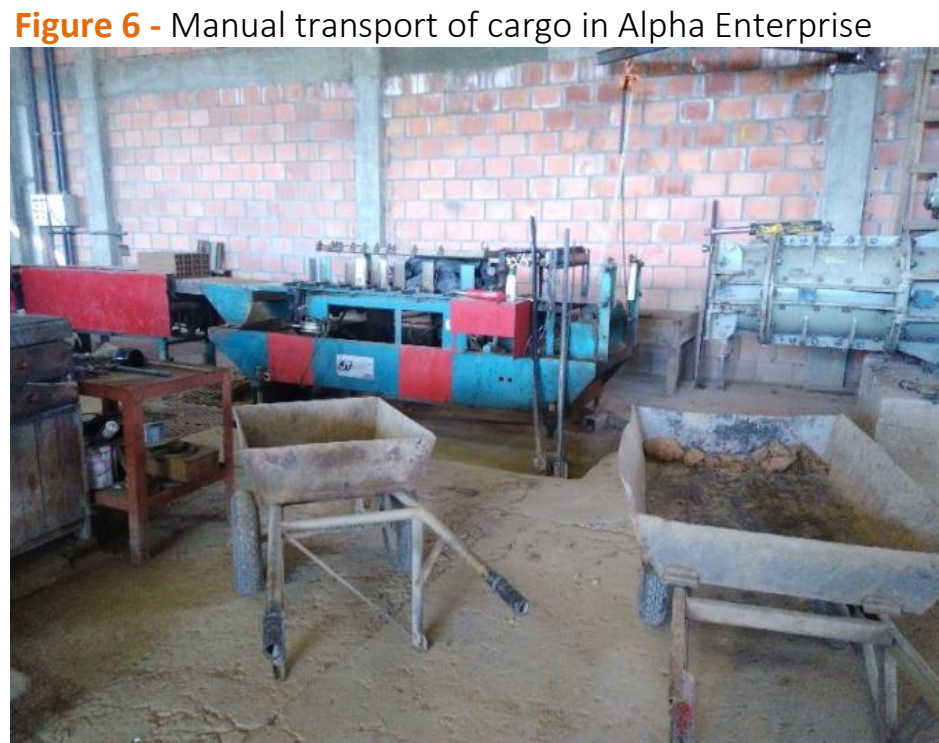

Source: Own.

\subsubsection{Fires}

The enterprise has fire extinguishers in strategic locations (Figure 7), properly signaled and unobstructed. However, it was observed that despite having sufficient outlets, which allow the evacuation of workers quickly and safely, they are not properly signaled.

Figure 7 - Use of fire extinguishers in Alpha Enterprise

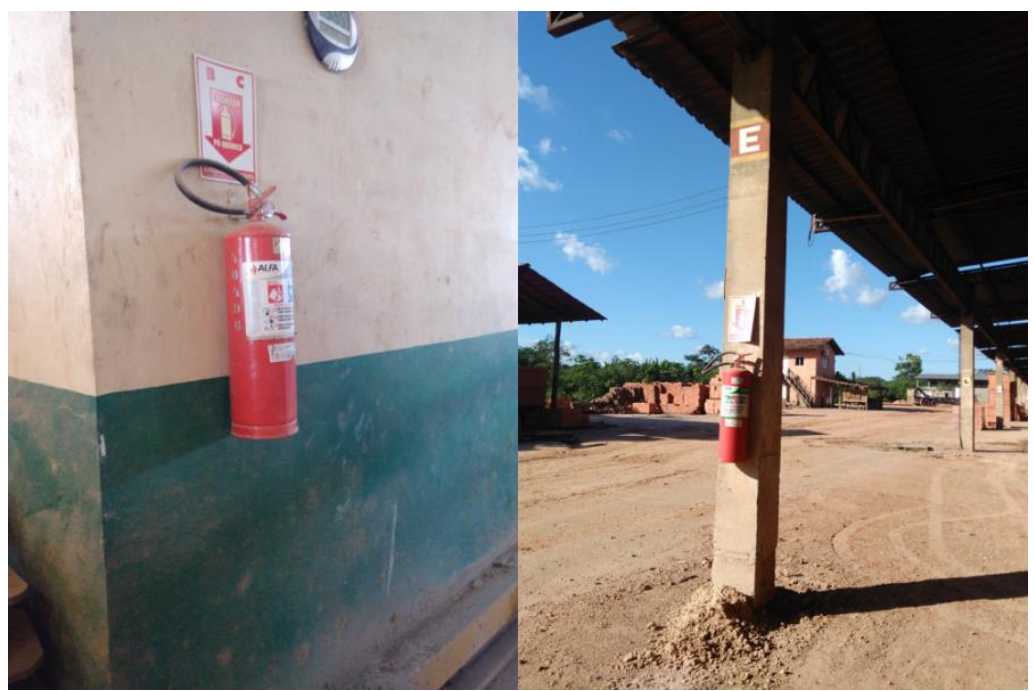

Source: Own

\section{Discussion}

Through the audit form applied in the enterprise, it became possible to analyze more deeply the regulatory norms implemented and partially implemented in the enterprise, allowing the opening for a greater discussion about its execution, operation and how the enterprise deals with and 
contributes to the health and safety of its workers. Based on the data obtained about each NR implemented in the enterprise, it was verified that not all of them comply with the basic safety concepts imposed by the regulations.

SESMT is linked to the degree of risk of the main activity and to the total number of employees of the establishment, but it is not deployed in the enterprise, because it has only 45 employees. In the meantime, the enterprise has a work safety technician, adopting the SESMT sizing in risk grade four (according to the norm), since it has already had the work of more than 80 employees and this number was recently reduced.

With regard to CIPA, the data found were satisfactory, since the enterprise complies with what is established in relation to its duties, operation, training and the electoral process. It was noted that the security technician visits the enterprise on a weekly basis to discuss safety and health issues in the workplace. In addition, the mapping of risks classified and represented by their due colors takes place, seeking to raise awareness among workers and reduce the number of work-related accidents and their health damage within the enterprise.

NR-6 states that the enterprise is obliged to provide the personal protective equipment (EPI) free of charge and in a perfect state of repair and operation, adequate to the risk that each worker is subject to. However, it has been noted that most of the enterprise's workers are not making proper use of EPI, especially with regard to protective helmets, which are only placed over the head and can be moved out with as little effort as possible. There was also little use of hearing protectors and masks, even with constant noise and dust. The enterprise should be concerned with monitoring and enforcing the correct use of EPI by workers, guiding them and training them on proper use, safekeeping and conservation. As well as providing appropriate clothing to the risks of thermal origin in which workers are exposed daily in the dryer.

PCMSO according to NR-9 aims at prevention, screening and early diagnosis of work-related diseases. This regulatory standard is directly linked to NR-4 since its structure is related to the SESMT dimensioning according to the degree of risk in which the enterprise fits. It was observed that although the enterprise is not within the sizing established in the SESMT, according to the Work Technician, because it has a number of employees below the established minimum, it counts on a doctor to make annual evaluations in its employees, analyzing the conditions of day-to-day operational risks, seeking to ensure the health of workers.

The NR-8, which talks about the buildings, aims to establish the technical requirements in the buildings, which guarantee the safety and comfort of the workers. Through the observations made in the enterprise, taking into account their branch and the material used in the manufacturing process, it was found that the passages of certain workplaces become slippery, especially on rainy days, and do not rely on non-slip materials, in addition to the floors showing protrusions and depressions, 
damaging the movement of people. It was also observed that in floors above ground there is no fall protection

With respect to NR-9, it was observed that the enterprise is concerned with the occurrence of environmental risks and that its employees are exposed daily with the chemical, physical and biological risks. In the case of a ceramics industry, daily contact with dust, noise, fungi, and bacteria occurs, among other factors that may endanger the health of workers. It became possible to observe that in the sawmill sector, where there is direct contact with high noise and residues, such as biomass, used in the burning process, all workers make proper use of hearing protection equipment and the smell. It is important to emphasize that not all sectors of the enterprise take the necessary precautions, even if there is contact with the most diverse agents. The enterprise should make better monitoring of these exposures to the risks, since the NR-9 is linked to the NR-6, dimensioning the protection equipment for each area.

It was observed that the machines and equipment of the enterprise do not have the proper demarcations, which are indispensable for the movement of material and workers safely. However, it has been observed that in the area of the extrusion process there is suspended movement of the production material on the workers, as well as the floors of the places where machines and equipment are installed and of the circulation areas, are dirty and in them are deposited objects and tools that may pose an accident risk, which is in complete disagreement with NR-12. Some machines do not have good conditions for the use, once observed that there were numerous stops in the productive process, due to problems in the own machine, that were solved of the superficial way only to continue the productive process and later they returned to occur.

Considering the characteristics of the enterprise, the materials used in the production process uses three types of clay (red, white and yellow) and their external storage, it was verified that there is not adequate signaling indicated by the standard. In contrast, the enterprise adopts the necessary measures with respect to signaling and identification to the risk of electric shock, access restriction, safety systems, as well as requiring only authorized persons to be able to move in these areas.

The enterprise uses a furnace for the burning of its products following the regulations of the NR-14 in relation to the coating with refractory material and complies with the limits of heat tolerance. It was observed that the enterprise is attentive with the exit of the gases burned of the chimney, adopting the technical norms on air pollution.

With the help of the safety technician, the enterprise seeks to measure chemical, physical and biological agents annually. According to the technician, the noise tolerance limit, which is present in the extrusion area, is below the limit established by the NR-15, that is, it cannot cause damage to the health of workers in this sector. However, they have access to EPI for the ears. According to observations in the production environment, the workers who are in the role of "deliverer" are the most exposed to the heat and also those who perform the most unhealthy service within the 
enterprise. However, it was not found that they have the necessary rest time established by the NR according to the level of work required. The enterprise should take measures related to the fatigue of these workers since they work 12 hours a day and this condition can cause a series of harms to their health.

With respect to ergonomics, it has been observed that there are many sectors in which the working conditions are not adapted to the work that is performed. In the brick stacking process, it was noted that the stacking workers do all the service standing and there are no chairs available for their rest, not obeying NR-17 for the work performed standing and the layout of seats for workers during breaks. In the laboratory of quality, there is no refrigeration for the worker, thus not obeying the effective temperature index that is established by the norm with respect to the comfort conditions for rooms and laboratories. The temperature should be between $20^{\circ} \mathrm{C}$ and $23^{\circ} \mathrm{C}$ and is usually at a temperature of $30^{\circ} \mathrm{C}$.

Finally, the enterprise provides firefighting equipment in strategic areas in compliance with NR-23 regulations. However, evacuation exits were not signaled and no existing alarm devices could be observed.

In this way, the norms that presented better performance were NRs 5 (CIPA), 7 (PCMSO), 8 (Buildings), 9 (PPRA), 14 (Furnaces) and 23 (Prevention of accidents). The standards with intermediate performance were NRs 6 (EPIs), 12 (safety in machines and equipment), 17 (Ergonomics) and 23 (fire prevention); and concluding, the norms with the most unsatisfactory results were NRs 4 (SESMT) and 15 (Insalubres). Figure 8 summarizes the discussion of the audit of occupational health and safety in the Alpha Enterprise through the presentation in the form of a radar chart.

Figure 8 - Radar chart resulting from audit

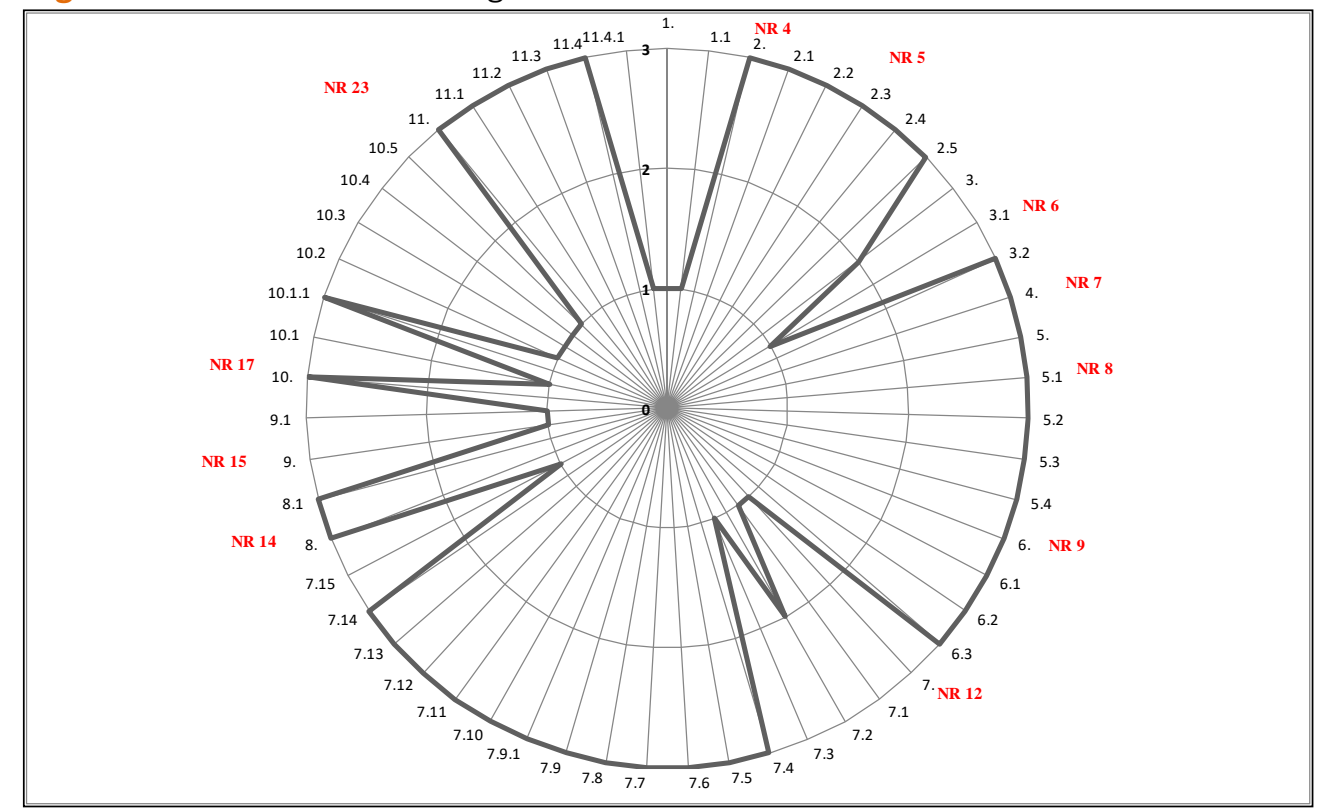

Source: Own 
Regarding the methodology used in the research, it allowed a greater understanding of the interaction between man and work, as well as of the socio-technical system. In addition, the importance of the audit to meet the human needs for the improvement of the accomplishment of the activities in the work is emphasized, according to lida (2005). Thus, with the application of the audit of occupational health and safety, the research allowed an intervention of the ergonomic action, since according to Daniellou \& Béguin (2007) there are a diversity of forms of ergonomic intervention that can be applied in the production or service by both ergonomists and non-trained personnel in the area, using the general standards or recommendations. Therefore, with the study of the NRs, the audit could be carried out resulting in the elaboration of the radar chart, to identify the risks, to analyze them and to evaluate them in more detail, as well as to verify the factors within the enterprise environment that could indicate accidents at work and consequently cause harm to the health of the worker.

Through the results obtained with the application of the audit form, it became possible to analyze more deeply one of the main objectives of ergonomics, according to Falzon (2007), that is directed to the people and worries about the security, health, and comfort in the work environment. In this way, three of the four ergonomic contribution steps were used, which are classified in (1) conception, (2) correction, (3) awareness according to lida (2005) to explore more deeply the data obtained. The audit allowed us to visualize the physiological characteristics within the physical ergonomics according to IEA (2019), as well as the use of ergonomics to meet the norms (in the case of the regulatory norms research) in line with Daniellou \& Béguin (2007).

With the ergonomics of design, we could use the observations made in the enterprise regarding the application of the norms with respect to their compliance and functioning, seeking to make a later analysis of what could happen in case of incorrect implementation and non-monitoring of the its compliance by both the enterprise and the employees, being able to cite as an example what was described previously about the employees of the enterprise that do not use the EPI in all the situations of risks that they are exposed.

With regard to correction ergonomics, it was sought to determine what types of changes could be made to improve workers' safety within the minimum established by each NR, such as increasing monitoring in the work sectors for compliance with standards, thereby entering in the third stage of contribution, which addresses awareness and could be made through the enterprise's requirement for all employees to make the correct use of the equipment according to the risk it is exposed or by creating an internal safety week and of work.

According to Abrahão et al. (2009), this research has methods and techniques of analysis to identify the problems caused to humans by the inappropriate use of artifacts, work organization and environments, which were detected through the observations made and the answers obtained with the application of the questionnaire. Once the occupational health and safety form was applied, the 
errors resulting from the incorrect implementation of NRs, such as NR-6 (EPI) and NR-12 (Machinery and Equipment), were detected, in breach of their respective ordinances, being able to discuss them and suggest ways of improvement.

Safety at work aims to promote improvements in the health and safety of workers, seeking to identify the risks, analyze them and evaluate them to eliminate or control them (Chibinski, 2011). Therefore, it can be stated with the material used to carry out this research, it was possible to comply with the development of safety at work, making it feasible to identify the risks for each standard (NR) implemented and analyzed within the enterprise, analyzing where errors occur, evaluating in relation to each activity performed, seeking to suggest options for its elimination or control.

\section{Conclusion}

The objective of this work was to carry out an audit of occupational health and safety of an enterprise in the ceramic sector of the Amazonas/Brazil, seeking to identify the priority sectors for the application of the audit instrument. By means of the results obtained and with the analysis of the checklist, together with the radar chart, it is believed that the objective was achieved.

With the main results obtained the study (1) allowed to analyze in a systematic way the activities developed within the enterprise; (2) detecting the risk factors in the different sectors; (3) identifying the regulatory norms that stand out most positively and negatively; and (4) ascertaining whether they are in agreement with what is established and evaluating whether or not the established criteria are being met. Regarding the limitations of the study, it is identified the application in only one enterprise as a single case study and as suggestions for future studies, it is indicated the application of the systematics in other companies of the branch with a view to characterizing the ceramic sector in the municipality.

The methodology used was fundamental to achieve the results obtained with this research, since with the case study it became possible to study the enterprise more deeply, providing a greater exploration, thus being able to observe in more detail the work sectors, making it easier the identification of risk factors within the enterprise. These results reinforce the use of Baxter \& Jack (2008), McCutcheon \& Meredith (1993), Barrat et al. (2011) and Voss et al. (2002).

It is believed that the enterprise in which the research was done can make use of the information contained in this study to reflect on the application of ergonomics throughout the organization. The relevance of this study is to demonstrate that ergonomic decisions can be made to improve safety, satisfaction, reducing errors and accidents, to improve the health and productivity of the entire enterprise. 
Repolho, T. M., \& Coelho, M. A. (2020, out./dez.). Audit of occupational health and safety in an enterprise of the ceramic sector in

\section{References}

Abrahão, J.; Sznelwar, L. I. ; Silvano, A.; Samet, M. ; \& Pinho, D. (2009). Introdução à Ergonomia: da Prática à Teoria. São Paulo: Edgard Blucher.

Barrat, M.; Choi, T. Y.; \& Li, M. (2011). Qualitative case studies in operations management: trends, research outcomes and future research implications. Journal of Operations Management, 29 (4), 329-342.

Baxter, P.; \& Jack, S. (2008). Qualitative case study methodology: study design and implementation for novice researchers. The Qualitative Report, 13 (4), 544-559.

Béguin, P. (2007). O ergonomista, ator da concepção. In: FALZON, Pierre. Ergonomia - Editora Blucher.

Benbasat, I.; Goldstein, D. K.; \& Mead, M. (1987). The case research strategy in studies of information systems. MIS Quarterly, 11 (3), p. 369-386.

Brasil. Ministério do Trabalho e Emprego. Portaria n³3, de 27 de outubro de 1983. NR-4 - Serviços Especializados em Engenharia de Segurança e em Medicina do Trabalho - SESMT, Brasília, DF, 31 out. 1983.

Brasil. Ministério do Trabalho e Emprego. Portaria n 8, de 23 de fevereiro de 1999. NR-5 - Comissão Interna de Prevenção de Acidentes - CIPA, Brasília, DF, 24 fev. 1999.

Brasil. Ministério do Trabalho e Emprego. Portaria n²5, de 15 de outubro de 2001. NR-6 Equipamento de Proteção Individual - EPI, Brasília, DF, 17 out. 2001.

Brasil. Ministério do Trabalho e Emprego. Portaria $n^{\circ} 24$, de 29 de dezembro de 1994. NR-7Programa de Controle Médico de Saúde Ocupacional - PCMSO, Brasília, DF, 30 dez. 1994.

Brasil. Ministério do Trabalho e Emprego. Portaria n 12, de 06 de junho de 1983. NR-8 - Edificações, Brasília, DF, 14 jun. 1983.

Brasil. Ministério do Trabalho e Emprego. Portaria n²5, de 29 de dezembro de 1994. NR-9 Programa de Prevenção de Riscos Ambientais - PPRA, Brasília, DF, 30 dez. 1994.

Brasil. Ministério do Trabalho e Emprego. Portaria 197, de 17 de dezembro de 2010. NR12 - Segurança no trabalho em máquinas e equipamentos, Brasília, DF, 24 dez. 2010.

Brasil. Ministério do Trabalho e Emprego. Portaria $n^{\circ} 12$, de 06 de junho de 1983. NR-14 - Fornos, Brasília, DF, 06 jun. 1983.

Brasil. Ministério do Trabalho e Emprego. Portaria n 3.214, de 08 de junho de 1978. NR15 - Atividades e operações insalubres, Brasília, DF, 06 jul. 1978.

Brasil. Ministério do Trabalho e Emprego. Portaria $n^{\circ} 3.751$, de 23 de novembro de 1990. NR-17Ergonomia, Brasília, DF, 26 nov. 1990.

Brasil. Ministério do Trabalho e Emprego. Portaria 221, de 06 de maio de 2011. NR-23 - Proteção contra incêndios, Brasília, DF, 10 mai. 2011.

Bureau Internacional do Trabalho. (2009). Introdução à saúde e segurança do trabalho. Genebra: ILO. 
Castro, T.; Okawa, C. (2016). Auditoria de segurança e saúde do trabalho em uma indústria de alimentos do estado do Paraná. Revista Produção Online, 16 (2), 678-704.

Chibinski, M. (2011). Introdução à segurança do trabalho. Curitiba: Instituto Federal Paraná.

Daniellou, F.; Béguin, P. (2007). Metodologia da ação ergonômica: abordagens do trabalho real. In: Falzon, P. Ergonomia. São Paulo: Edgard Blucher.

Daniellou, F. (2007). A ergonomia na condução de projetos de concepção de sistemas de trabalho. In: Falzon, P. Ergonomia. São Paulo: Edgard Blucher.

Dul, J.; \& Weerdmeester, B. (2004). Ergonomia Prática. 2a ed. rev e ampl. - São Paulo: Edgard Blucher.

Falzon, P. (2007). Ergonomia. São Paulo: Edgard Blucher.

Ferreira, L.; \& Peixoto, N. (2012). Segurança do Trabalho I. Rio Grande do Sul: Colégio Técnico Industrial de Santa Maria.

Guérin, F. et al. (2001). Compreender o trabalho para transformá-lo: a prática da ergonomia. São Paulo: Blucher: Fundação Vanzolini.

lida, I. (2005). Ergonomia: projeto e produção. 2a edição rev. e ampl. - São Paulo: Edgard Blucher.

IEA - International Ergonomics Association. (2018). What is ergonomics? Retrieved from: https://www.iea.cc/whats/index.html.

Kvale, S. (1996). Interviews: an introduction to qualitative research interviewing. London: Sage.

Lamonde, F. (2007). As prescrições dos ergonomistas. In: Falzon, P. Ergonomia. São Paulo: Edgard Blucher.

Marconi, M. A.; \& Lakatos, E. M. (1996). Técnicas de pesquisa: planejamento e execução de pesquisas, amostragens e técnicas de pesquisa, elaboração, analise e interpretação de dados. 3. Ed. São Paulo: Atlas.

McCutcheon, D. M.; \& Meredith, J. R. (1993). Conducting case study research in operations management. Journal of Operations Management, 11 (3), 239-256.

Miguel, P. A. C. (Org.). (2012). Metodologia de pesquisa em engenharia de produção e gestão de operações. 2. ed. Rio de Janeiro: Elsevier: ABEPRO.

Oliveira, J. C. (2003). Segurança e saúde no trabalho: uma questão mal compreendida. São Paulo em Perspectiva, 17(2), 03-12.

Rocha, G. C. (2004). Trabalho, saúde e ergonomia: relação entre aspectos legais e médicos. São Paulo: Juruá.

Ruiz, V. S.; Araújo, A. L. L. (2012). Saúde e segurança e a subjetividade no trabalho: os riscos psicossociais. Revista Brasileira de Saúde Ocupacional, 37 (125), 170-180.

Servo, L. M. S.; Salim, C. A.; Chagas, A. M. R. (2011). Saúde e segurança no trabalho no Brasil: os desafios e as possibilidade para atuação do executivo federal. In: Chagas, A. M. R.; Salim, C. A.; Santos, L. M (Org.). 2011. Saúde e segurança no trabalho no Brasil: aspectos institucionais, sistemas de informação e indicadores. Brasília: IPEA. 
Silva, E.; \& Menezes, E. (2005). Metodologia da pesquisa e elaboração de dissertação. 4. ed. Florianópolis: UFSC.

Vergara, S. C. (2009). Métodos de coleta de dados no campo. São Paulo: Atlas.

Voss, C.; Tsikriktsis, N., \& Frohlich, M. (2002). Case research in operations management. International Journal of Operations \& Production Management, 22 (2), 195-219.

Yin, R. K. (1994). Case Study Research, Design and Methods. 2nd ed. Newbury Park: Sage Publications.

Recebido em: 26 abr. 2019 / Aprovado em: 09 out. 2019

Para referenciar este texto

American Psychological Association (APA)

Repolho, T. M., \& Coelho, M. A. (2020, out./dez.). Audit of occupational health and safety in an enterprise of the ceramic sector in the state of Amazonas/Brazil. Exacta, 18(4), 820-841. https://doi.org/10.5585/exactaep.v18n4.13731. 